\title{
Developing Dayah as Religious Tourism Destination in Aceh
}

\author{
Heriani, M.Baiquni, Djoko Wijono and Yulia Arisnani Widyaningsih \\ Doctoral Degree of Tourism Studies, School of Postgraduate Studies, \\ Gadjah Mada University
}

Corresponding author: heriani@mail.ugm.ac.id

\begin{abstract}
ARTICLE INFO
ABSTRACT

Received

27 January 2018

Accepted

13 March 2018

Available online

30 March 2018

Aceh has several religious tourism destinations, especially the historic mosques and the graves of the Ulama but it turns out that many tourists also come and visit Dayah. The flow of tourist arrivals to Dayah has not been well organized, whereas the potential of Dayah as a religious tourism destination is very large to be developed. This study aims to provide an overview of the potential and strategy of Dayah development as one of the religious tourism destinations in Aceh. The research method used in this research is qualitative with observation and interview based on primary and secondary data. The results show that some Dayah in Aceh who have great potential need to be developed as a religious tourism destination. The potential development efforts can be through several strategies that involve the role of government, Ulama and Dayah managers and the Dayah community.
\end{abstract}

Keywords: Dayah, potential, strategy, religious, tourism

\section{Introduction}

\section{Background}

Tourism in Aceh is currently experiencing a fairly rapid development, one indicator is the number of tourists both local and abroad are constantly increasing. It can be seen from the data of the Central Bureau of Statistics of Aceh in 2009 shows the number of foreign tourists visiting Aceh is 10,000 people and in 2012 increased to 13,099 people. Aceh has a lot of tourism potential, including nature, historic sites, tsunami relics and of course a culture that can not be separated from Islam, such as Islamic sites, mosques, celebrations of Islamic holy days and religious events are the potential of Aceh's religious

http://ojs.unud.ac.id/index.php/eot tourism that some have developed. However, there is one potential of Aceh's religious tourism that has not been developed, whereas the potential has a tremendous attraction both for local tourists, especially foreign tourists abroad, especially Malaysia. The intended potential is Dayah in Aceh.

Dayah is a traditional Islamic educational institution that still survive to this day. When viewed from the national context, Dayah is one of the pillars of Islamic education in Indonesia that existed long before the Indonesian state itself was born (Suyanta, 2012). Dayah can not be released with Aceh, it is because Dayah is the identity of Islam and indigenous Aceh, although its spirit and spirit still comes from the Islamic education system 
practiced by the Prophet Muhammad SAW during early Islam.

Dayah has an important meaning for Aceh, one of them in producing Ulama that guard and guide the government and society to remain in the corridor of Islamic teachings, as well as giving birth to Human Resources with religious knowledge and other knowledge that will be useful for society and country. When viewed from a historical cultural point of view, according to Abu Bakar, Dayah in Aceh can be regarded as a training center that automatically becomes the center of Islamic culture that is endorsed or instituted by the community in Aceh. The existence and role of Dayah that has been centuries in Aceh is not only known in Aceh and Indonesia, but also abroad, especially the Asean countries. Not a few of them who come to Dayah just visiting to see, even stay to learn some time. This indicates that Dayah is not merely as an educational institution, but it can be developed as one of religious tourism destination. Therefore, the potential and strategy of Dayah development need to be studied further through this research.

\section{Research Objective}

Objective of the research is to understand and provide an overview of the potential and strategy of Dayah development as one of the religious tourism destinations in Aceh.

\section{Literature review}

\section{Religious Tourism}

Religious Tourism is a tour based on belief in a religion, with the aim to improve faith and belief in the religion. The report of FICCI and YES BANK Ltd. (2012) entitled "Diverse Beliefs: Tourism of Faith Religious tourism gains ground" the travel with the core motive of experiencing religious forms, or the products they induce, like art, culture, traditions and architecture. In the beginning religious tourism is a person's journey for pilgrimage and performs obligations in his religion in places believed to be holy land in his holy books, such as mecca, gangga, jerusalem and others. Along with the development of religious tourism concept began to expand, as proposed by Cevallos (2016), the concept of religious tourism is very much and we can divide this kind of tourism in the next: (i) People that look for a religious experience, (ii) People that visit sacred places for cultural reasons, (iii) People that visit sacred places because the roads, the paths, the environment around this places is beautiful, and (iv) People, that attend religious events as spectator

Cevallos (2016) argues that the journey to attend religious activities is religious tourism. Based on the concept, visiting the place of religious education to attend religious events or religious studies within a certain time can also be classified as a form of religious tourism.

\section{Methodology}

This research uses qualitative method by collecting data through observation, interview and literature study. Interviews were conducted with ulama dayah, dayah managers and the government, in this case the Dayah Education Development Board, Aceh Province. With the selection of informants by purposive sampling. The data analysis used is qualitative descriptive. The type of data required in this study is divided into two, namely primary data and secondary data. Primary data will be obtained through observation (observation) and interview (interview). While the secondary data obtained from the documentation of text, images, books, articles from various media to support the primary data.

e-ISSN: 2407-392X. p-ISSN: 2541-0857 


\section{Results and Discussion}

\section{Dayah Potential as Religious Tourism Destination}

What is Dayah? The Dayah word is derived from the Arabic word "zawiyah". The term zawiyah according to Ishak (2010), literally means angle, which is believed by the people of Aceh where the mosque mosque corner functioned by the Prophet Muhammad to teach the companions in early Islam. The term zawiyah eventually turned into deyah or dayah due to the influence of the Aceh language that does not have the sound " $\mathrm{z}$ " and tend to shorten (Jalil, 2002). Dayah is the name of Islamic educational institutions in Aceh, in some areas in Indonesia known as pesantren originating from Java.

In general, the dayah is still strong in maintaining the traditional model of Islamic education. The traditional Dayah is called Dayah Salafi ${ }^{l}$ because its scholarship refers to and based on the books written by salafi Ulama $^{2}$ called yellow books. Despite its centuries, Dayah salafi retains its traditional components, such as cottages, mosques, teungku / kyai, santri, and classical books to this day. All these components are mutually exclusive and interrelated, so called by the society that has a typical culture of traditional society in rural areas marked by embedded way of life that is collective which is one manifestation of the spirit of working together (gotong royong) commonly found in rural communities (Suyanta, 2012). This is what makes Dayah referred to as one of Aceh's cultural identity and strength.

\footnotetext{
1 Salafi is a stream of thought that puts forward the syar'iyah nashes of various kinds of thinking both ways of work, which always commitment to the guidance of the Prophet and the guidance of the Companions both in scientific and practice.
}

The number of traditional Dayah is very much and spread throughout Aceh, some recorded by the government in this case the Aceh Education Board Dayah Aceh, but also there is not yet. Along with the development of education, Dayah with modern education system like some boarding school in Java also have exist in Aceh. Dayah type is known as Dayah Terpadu or Modern, where the curriculum and education system refers to the National education system. Data of Dayah can be seen in Table 1.

Table 1. Number of Dayah in Aceh

\begin{tabular}{|c|c|c|c|}
\hline \multirow[t]{2}{*}{ No. } & \multirow[t]{2}{*}{ City/Region } & \multicolumn{2}{|c|}{ Dayah type } \\
\hline & & $\begin{array}{c}\text { Salafiah/Tr } \\
\text { aditional }\end{array}$ & $\begin{array}{c}\text { Integrated/ } \\
\text { Modern }\end{array}$ \\
\hline 1. & Sabang & 1 & 2 \\
\hline 2. & Banda Aceh & 4 & 4 \\
\hline 3. & Aceh Besar & 59 & 24 \\
\hline 4. & Pidie & 42 & 2 \\
\hline 5. & Pidie Jaya & 42 & 4 \\
\hline 6. & Bireun & 70 & 5 \\
\hline 7. & North Aceh & 120 & 16 \\
\hline 8. & East Aceh & 42 & 9 \\
\hline 9. & Langsa & 10 & 1 \\
\hline 10. & Aceh Tamiang & 5 & 5 \\
\hline 11. & Bener Meriah & 3 & 14 \\
\hline 12. & Aceh Tengah & 10 & 10 \\
\hline 13. & Gayo Lues & 11 & 3 \\
\hline 14. & $\begin{array}{l}\text { Aceh } \\
\text { Tenggara }\end{array}$ & 3 & 19 \\
\hline 15. & Aceh Jaya & 11 & 3 \\
\hline 16. & Aceh Barat & 21 & 8 \\
\hline 17. & Nagan Raya & 8 & 1 \\
\hline 18. & $\begin{array}{l}\text { Aceh Barat } \\
\text { Daya }\end{array}$ & 15 & 4 \\
\hline 19. & Aceh Selatan & 4 & 3 \\
\hline 20. & Subulussalam & 3 & 10 \\
\hline 21. & Aceh Singkil & 3 & 4 \\
\hline 22. & Simeulue & 5 & 2 \\
\hline & Total & 492 & 153 \\
\hline
\end{tabular}

Source: Dayah Education Development Board, Aceh Province (2017)

Based on the Table 1, the number of Dayah Traditional / Salafi larger than integrated Dayah. It is a proof of the existence of traditional Dayah / Salafi in Aceh that has survived to this day. The data above also shows the amount of religious tourism potential that can be developed in Dayah 
Aceh. Some of these Dayahs have actually been accustomed to receiving visitors,. As an experience expressed by one of the salafi dayah managers who used to receive guest visits:

\begin{abstract}
"Sometimes they come do not use travel, maybe because there is a pointer direction, sometimes there is a new come straight in here go on, or sometimes have been traveling where to go, finally go home, while waiting for the plane's schedule ..so stop here, give us donation" $(A B D)^{3}$.
\end{abstract}

ABD said that some guests who come, there are sometimes with travel agent, there are also who come alone. They are usually tourists who come on vacation and after touring the attractions, they usually stop at dayah while waiting for flight schedule. Most of tourists bring donation to dayah. Some of them came with donation and study at dayah. Many of them are from outside Aceh such as from Malaysia

"There are also from malaysia 300 people, they take the program every year, may be Islamic tour... every year it learn to other area" (ABD.)

Even though Dayah's visitors are mostly Muslim, Dayah began to receive non-Muslim visitors, of course with the requirements set by Dayah. ABD said that:

"We are open, sometimes even some nonMuslims, yesterday someone came from America, then I permission with Abu (leader of Dayah) and he permit. We make an invitation to the people here, if maulid we have a lot of guests, then the American guest see how the hospitality of the Muslims in receiving the guests and how happy to glorify the birthday of the the Prophet Muhammad (mauli.)"(ABD).

\footnotetext{
${ }^{3} \mathrm{ABD}$ is a dayah manager in Banda Aceh and is
the son-in-law of the leader of Dayah. (Initial name

${ }^{3} \mathrm{ABD}$ is a dayah manager in Banda Aceh and is
the son-in-law of the leader of Dayah. (Initial name use to maintain informant privacy)
}

Some information from Dayah is directly describes that the dayah is very potential to be developed as a religious tourism destination in Aceh. Good communication and cooperation between leaders and management of the dayah with the government and the community around the dayah needed further to develop the strategy of developing the dayah.

\section{Strategies for developing Dayah as a religious tourism destination}

Dayah development as a religious tourism destination requires a strategy with good coordination among all stakeholders. Aceh Dayah Education Development Board as one of the government institutions also gives positive signal of support to the development of the dayah;

\begin{abstract}
"Yes.. very happy if there are people outside Aceh going to Aceh who want to see the development of dayah in Aceh. It was incredible". we really want that Islamic tourism, because Aceh is Serambi Mekkah (porch of Mecca). there is an advantage for the area from tourism, right? , then also people outside of Aceh come here to bring money, and definitely spend, at least at the hotel stay, then he also ate, buy souvenirs, it's all income for the people of Aceh and the government because there are taxes" (BPPD).
\end{abstract}

In addition to support from the Dayah Education Development Board, the main support of the Tourism Office is also a major driver. Synergy of all parties is needed to start the strategy of developing the dayah as a religious tourism destination. Flowchart of strategies for developing a Dayah as a religious tourism destination can be seen in Table 1. 


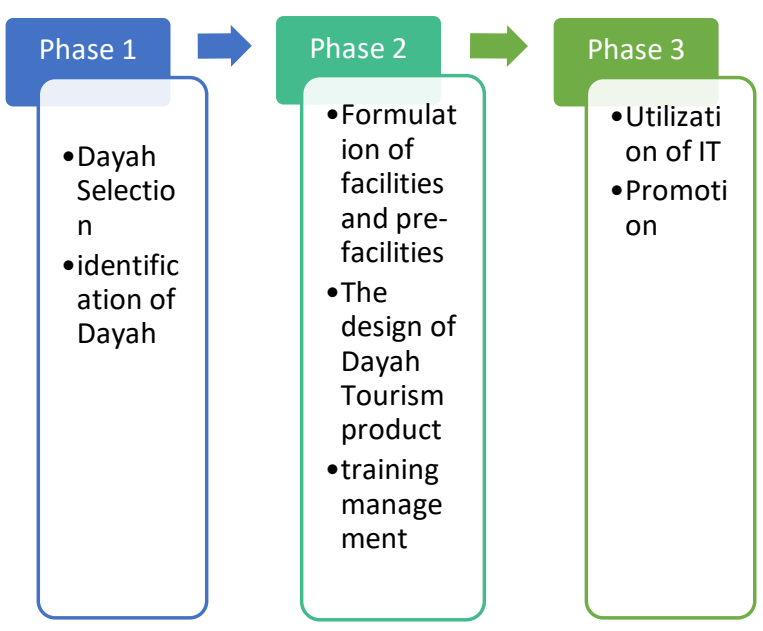

Figure 1. Flowchart of strategies for developing a Dayah as a religious tourism destination

Based on the Figure 1, strategies for developing a dayah as a religious tourism destination can be described as follows:

1. The first Phase (Dayah selection and identification).

The first phase consists of selecting several potential Dayahs to become religious tourism destinations. Then proceed with studying the organization and work of the dayah-dayah that will be used as an object of development studies. The activities focus on the organization and work system that support Dayah's core activities, namely accommodation, food, beverages, entertainment, sports and other activities in the Dayah.

2. The second Phase

a) Formulation of Supporting Facilities and Infrastructure Activities.

This phase begins with choosing the activities to be used to support the core activities of Dayah, which is then formulated as an activity that will be given the content of tourism culture, facilities, infrastructure as a basic guidelines of its management

b) Basic Management Guide.

The results of the study on basic management guidelines are further communicated in the form of seminars and FGD (Focuss Group Discussion) with the management of Dayah. The results of the deliberations are expected to be applied gradually in accordance with the existing human resource capabilities in the Dayah.

c) Socialization of tourism culture

After the management guidance has been agreed, the activities of tourism culture in Dayah, need to be developed such as hospitality.

3. The third Phase

a) Creating Dayah Website

Dayah website is required as access to guide and promotion media about Dayah concerned. In addition, the Website is also used as a communication medium for follow-up activities as well as various parties.

b) Creating Dayah Promotion Packages.

Dayah generally has no experience as a tourist manager, then the promotional instruments will be provided by the Department of Tourism, such as leaflets and brochures.

\section{Conclusion}

Dayah as the center of Islamic religious education in Aceh, not only has the attraction for local people to come just to visit, attend the anniversary of Islamic holidays, and stay to learn. But the enthusiastic foreign tourists, especially Muslim tourists are also quite large. This is a great opportunity for the development of dayah as a new tourist destination of religious tourism. Good and sustained communication and coordination especially between the dayah, the Dayah Education coaching agency, and the Tourism Office to develop the development strategy is the key to the success of Dayah as one of the religious tourism destinations in Aceh.

\section{References}

Cevallos, M. C. R. (2016) Religious Tourism. Universidad De Especialidades Turisticas.

Ishak, I. (2010) Apresiasi terhadap Peranan Dayah dalam Pembinaan Masyarakat di Sekitarnya. M. Hasbi Amiruddin (ed.) Apresiasi Dayah Sebagai Lembaga Pendidikan Islam di Aceh. Banda Aceh: Pengurus Besar Persatuan Dayah Inshafuddin. 
E-Journal of Tourism Vol.5. No.1. (2018): 40-45

Jalil, T. A. (2002) Adat Meukuta Alam. Banda Aceh: Pusat Dokumentasi dan Informasi Aceh.

Suyanta, S. (2012) 'Idealitas kemandirian dayah', Jurnal Ilmiah Islam Futura, 11(2), pp. 16-37. 